\title{
Acinar Cell Carcinoma of the Pancreas with Postoperative Lipase Hyper-Secretion Syndrome: Case Report and Review of the Literature
}

\author{
Walid Elhaj Abdelrahim, ${ }^{1 *}$ Kamal Elzaki Elsiddig, ${ }^{1}$ Mohamed Elfatih, ${ }^{1}$ \\ Mohamed Elhassan Akoad, ${ }^{2}$ Bader Eldin Margani, ${ }^{1}$ EAG Khalil ${ }^{3}$ \\ ${ }^{1}$ Department of Surgery, Faculty of Medicine, University of Khartoum, Sudan \\ ${ }^{2}$ Department of Transplantation, Lahey Clinic, Tufts University, USA \\ ${ }^{3}$ Department of Clinical Pathology \& Immunology, Institute of Endemic Diseases, \\ University of Khartoum, Sudan
}

\begin{abstract}
Lipase hyper-secretion syndrome (LHS) is a rare para-neoplastic syndrome that has been reported in association with acinar cell carcinoma (ACC). There are only a few LHS cases in the literature. A 68-yearold male presented with obstructive jaundice. ERCP findings showed distal common bile duct (CBD) stricture. Contrast-enhanced CT showed pancreatic head and uncinate process $6 X 5 \mathrm{Cm}$ hypodense mass. Three weeks after admission, Whipple's procedure and Child's reconstruction were done. H\&E and Immuno-histochemistry showed acinar cell carcinoma (ACC). On day three postoperatively the patient developed severe artharitis and inability to walk. Rheumatoid arthritis workup turned to be negative and uric acid level was within normal range. The diagnosis of lipase hypersecretion syndrome (LHS) was made retrospectively. Post-operative lipase hyper-secretion syndrome should be considered in patients with polyarthritis and negative rheumatoid workup in patients with the rare pancreatic acinar cell carcinoma.
\end{abstract}

Keywords: acinar cell carcinoma, Lipase hyper-secretion syndrome, chemotherapy.

\section{INTRODUCTION}

Pancreatic acinar cell carcinoma (ACC) is a rare tumor that constitutes $1-2 \%$ of primary pancreatic neoplasm [1,2]. ACC predominantly affects males with a mean age of 56 to 64 years at presentation [3]. ACC usually presents with abdominal pain, weight loss and less commonly jaundice in $12-20 \%$ of cases $[4,5]$. A rare para-neoplastic syndrome called lipase hyper-secretion syndrome (LHS) was reported in association with ACC. The first case report of ACC of the pancreas associated with LHS was made in 1908 by Berner [6] who described a so-called functioning acinar cell carcinoma of the pancreas. The first appropriate interpretation of the patho-physiology was provided by Auger [7] in 1947. There are only a few case reports of LHS described in the literature [8-11]. LHS is characterized by poly-arthralgia, subcutaneous fat necrosis and esinophilia. ACC has earlier presentation, pancreas body and tail are more commonly affected and the disease is more localized compared to pancreatic adenocarcinoma (AC). The resection rate is higher even with large tumors and it ranges between $45-64 \%$ in comparison to $<10 \%$ in AC. Schmidt and colleagues [12] reported that stage-specific 5-year survival was significantly better for resected ACC compared to AC (stage I: $52.4 \%$ vs $28.4 \%$; stage II: $40.2 \%$ vs $9.8 \%$; stage III: $22.8 \%$ vs $6.8 \%$; stage IV: $17.2 \%$ vs $2.8 \%$ ). The preoperative diagnosis and clinical picture are non-specific. Although CT appearances in favor of ACC include: sizable, solitary, well-defined, heterogeneous hypo-dense mass with a well-defined enhancing capsule [13]. However, the diagnosis is usually by histopathology following resection in adjunct to Immunohistochemical staining. ACC cells show positive reaction with trypsin (100\%), chymotrypsin (38\%), lipase (77\%), and amylase (31\%) [14]. Pathogenesis of ACC is poorly understood, genetic and epigenetic genomic aberrations (e.g. TP53 gene and APC/ $\beta$-catenin pathway alterations) have been suggested to play a role in ACC onset, pathogenesis and poor survival $[2,15$, $16]$. 


\section{CASe SCEnario}

A 68-year-old married, male and ex-banker from a village, Gezira State, Central Sudan presented with epigastric pain for 3 months, yellowish discoloration of sclera for 2 months, dark urine, pruritus, and anorexia and weight loss. ERCP showed: distal common bile duct (CBD) stricture. A stent $10 \mathrm{Cm}, 7$ FR was deployed to the CBD. He denied any past history of jaundice, blood transfusion or surgical operations. He was hypertensive for $>10$ years on Lisinopril, $10 \mathrm{mg}$ once daily. In addition, to intermittent arthralgia for 3 years labeled as gouty arthritis (on allopurinol $100 \mathrm{mg} /$ daily). He developed pulmonary edema 3 years ago and was on Furosemide 40 mgdaily). On examination, he was pale, not jaundiced and no signs of chronic liver disease were elicited. Cardiovascular system and Chest were clear. Abdominal examination: showed no ascites or palpable masses. Hb was 99 grams/L, platelets count of $227 \times 10^{3} \mu / \mathrm{L}$, esinophils $0.3 \times 10^{3} \mu / \mathrm{L}$. Serum creatinine was $0.9 \mathrm{mg} / \mathrm{dl}$, serum of $\mathrm{K}^{+}$ $2.8 \mathrm{mmol} / \mathrm{L}$, serum $\mathrm{Na}^{+} 140 \mathrm{mmol} / \mathrm{L}$, INR 1.02. Albumin $37 \mathrm{grams} / \mathrm{L}$, total bilirubin $0.8 \mathrm{mg} / \mathrm{dl}$, ALP 135U/L, AST/ALT 10/16.8 IU/L and serum carbohydrate antigen (CA) $19-9 \quad 0.4 \mathrm{ng} / \mathrm{dl}$. US examination of the abdomen showed a mass in the pancreatic head, probably carcinoma. Dilated intra and extrhepatic biliary tree and CBD $[12 \mathrm{~mm}]$. CT scan showed a pancreatic head and uncinate process hypo-dense mass $[6 \times 5-\mathrm{cm}]$, with $180^{\circ}$ abutment of SMV and SMA. The first jejunal branch was lifted by the tumor (Figure 1). As routine hospital practice the patient was consented for surgery. Surgery findings were negative for ascites, liver metastases, lymphadenopathy and peritoneal seedlings. A small $1 \mathrm{X} 2 \mathrm{Cm}$ nodule in the proximal jejunum close to the dudeno-jejunal (DJ) flexure was seen. A well circumscribed, firm and whitish $5 \mathrm{X} 4 \mathrm{Cm}$ pacreatic head mass was seen. The mass involved the uncinate process and it was separable form the SMA and SMV. A Whipple's procedure and Child's reconstruction were accomplished. Drains inserted for serial amylase assessment on days 3 and 5 with the following results: 181 and $30 \mathrm{IU} / \mathrm{L}$ respectively. Oral intake was initiated on day5 postoperatively. Drained were removed on day 6 . Histopathology results of a $6 \times 5.5 \times 3 \mathrm{~cm}$ pancreatic tissue with surrounding small intestine, showed pancreatic acinar cell carcinoma.

On day three postoperatively the patient developed bilateral knees, ankles and hands small joints' pain and swelling to the extent that he couldn't get out of bed. The Rheumatologist assessed the patient and the Rheumatology work up was negative [anti-CCP 7.4 U/L, RF $65.6 \mathrm{IU} / \mathrm{L}$, ESR $5 \mathrm{~mm} / \mathrm{hrs}$, serum uric acid $5.1 \mathrm{mg} / \mathrm{dL}$ ]. Diclofenac sodium $75 \mathrm{mg}$ therapy was initiated. The patient was assessed for LHS after the histopathology result and the lipase level was normal day 6 post operatively [40 $\mathrm{U} / \mathrm{L}]$. The patient was discharged on day 8 post-operatively and was symptom-free when he was seen a month after resection. The patient received 12 sessions of Gemcitabine-based chemotherapy.

This report aims to highlight the importance of maintaining high index of suspicion for this rare syndrome in patients with acinar cell carcinoma.

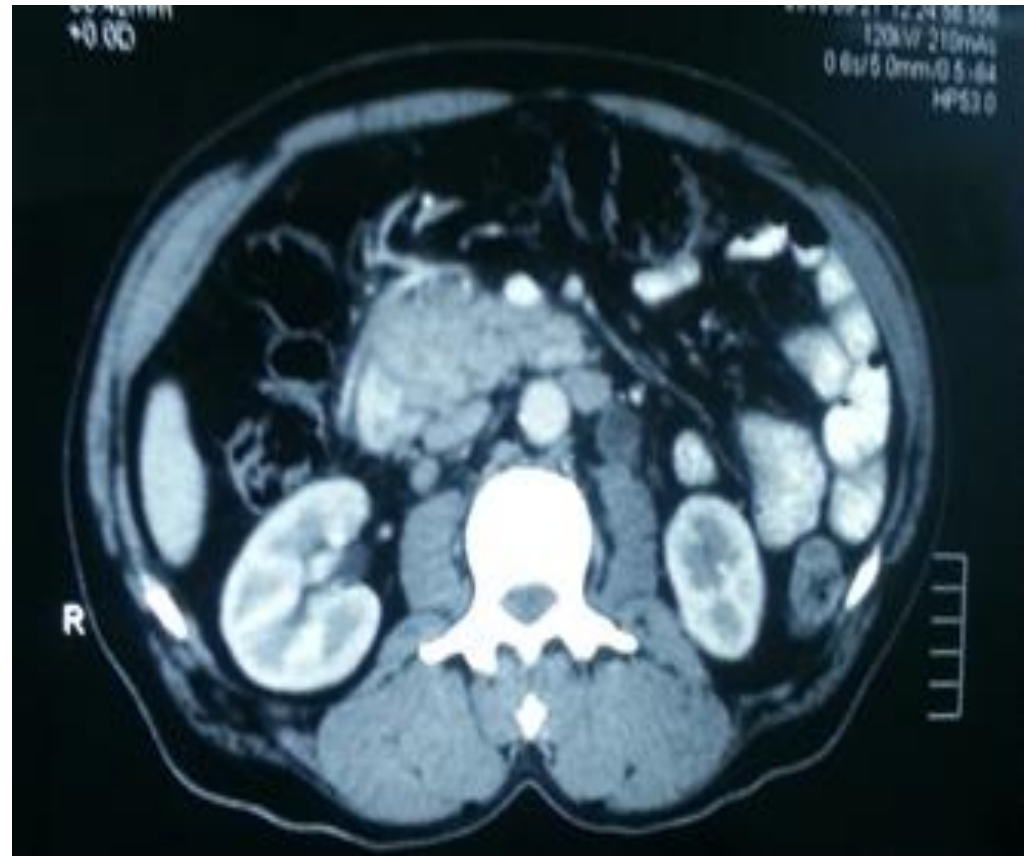

Figure1. An uncinate process mass lifting the first part of the jejunal with abutment of superior mesenteric $\operatorname{artery}(S M V)$. 


\section{DISCUSSION}

Pancreatic ACC is a rare malignant epithelial neoplasm that exhibits exocrine enzyme production. LHS occurs only in 10-15\% of patients with ACC. This para-neoplastic syndrome shows elevated serum lipase activity and peripheral blood eosinophilia associated with clinical signs of subcutaneous fat necrosis and polyarthritis. Less commonly osteolytic lesions have been described. Serum amylase activity is increased in only $30 \%$ of cases of LHS [16, 17]. Our patient had severe arthritis with negative rheumatology work up and his lipase level was normal on day 6 postoperatively. However, his symptoms completely resolved one month after resection.

Currently, surgical resection is the only curative approach to pancreatic ACC [18, 19]. Kitagami and colleagues [19] reported that the 5-year survival rate for patients with resected ACC was 43.9\%, with a median survival time (MST) of 41 months. On the other hand, the 5-year survival rate for unresected cases was $0 \%$, with a MST of 3 months. Although there is no doubt that surgery is the mainstay for the treatment of ACC, a high recurrence rate of $72 \%$ following surgical resection has been reported. Therefore, effective chemotherapy is necessary to improve the clinical outcome. However, chemotherapy regimens have not been established due to the rarity of this disease $[19,20]$. A study carried out in the Memorial Sloan-Kettering Cancer Center of 18 ACC patients who received in-homogeneous chemotherapy regimens, containing Gemcitabine, 5-FU, Leucovorin, Mitomycin, Cisplatin, Cytarabine, Irinotecan, Caffeine and Doxorubicin, reported partial responses (PRs) and stable disease in some patients. It is clearly evident that a protocol for the ACC adjuvant chemotherapy is highly needed [21].

In conclusion, post-operative lipase hyper-secretion syndrome should be considered in patients with polyarthritis and negative rheumatoid workup in patients with the rare pancreatic acinar cell carcinoma.

\section{List of abbreviations:}

ACC: acinar cell carcinoma

SMA: superior mesenteric artery

MV: superior mesenteric vein

DJ: duodeno-jejunal flexure

VIP: $\quad$ vasoactive intestinal peptide

PP: pancreatic polypeptide

\section{Ethical and publication approval:}

Ethics approval was obtained from the Ethics Committee of the Faculty of Medicine, University of Khartoum, Sudan.

Written informed consent was obtained from the patient for publication of this case report and any accompanying images. A copy of the written consent is available for review by the Editor-in-Chief of this journal.

\section{Competing interest:}

The authors declare that they have no competing interests.

Funding: This research did not receive any specific grant from funding agencies in the public, commercial, or not-for-profit sectors.

\section{Authors' contribution:}

WE and KAE contributed to the writing of the manuscript and the management of the patient. BEM performed the histopathology/immunohistochemistry. WE, KAE, ME, MEA, BEM and EAGK have contributed to writing, revising and editing of the manuscript. All authors read and approved the final manuscript 


\section{REFERENCES}

[1] Matos JM, Schmidt CM, Turrini O, Agaram NP, Niedergethmann M, Saeger HD, Merchant N, Johnson CS, Lillemoe KD, Grützmann R. Pancreatic acinar cell carcinoma: a multi-institutional study. J Gastrointest Surg 2009; 13.8: 1495-1502.

[2] La Rosa S., Sessa F., Capella C. Acinar Cell Carcinoma of the Pancreas: Overview of Clinicopathologic Features and Insights into the Molecular Pathology. Front Med (Lausanne). 2015; 2: 41. Published online 2015 Jun 15. doi: 10.3389/fmed.2015.00041.

[3] Seth AK, Argani P, Campbell KA, Cameron JL, Pawlik TM, Schulick RD, Choti MA, Wolfgang CL.. Acinar cell carcinoma of the pancreas: an institutional series of resected patients and review of the current literature. J Gastrointest Surg 2008; 12:1061-1067.

[4] Wisnoski NC, Townsend CM Jr, Nealon WH, Freeman JL, Riall TS. Patients with acinar cell carcinoma of the pancreas: a population-based comparison to pancreatic adenocarcinoma. Surgery 2008; 144.2: 141-148.

[5] Kitagami H, Kondo S, Hirano S, Kawakami H, Egawa S, Tanaka MAcinar cell carcinoma of the pancreas: Clinical analysis of 115 patients from Pancreatic Cancer Registry of Japan Pancreas Society. Pancreas 2007; 35:42-46.

[6] Berner Subkutane Fettgewebsnekrose . Virchows Archiv für pathologische Anatomie und Physiologie und für klinische Medizin S1908; 193 (3): 510-518.

[7] Auger C. Acinous cell carcinoma of the pancreas with extensive fat necrosis. Arch Pathol 1947; 43:400-405.

[8] Potts DE, Mass MF, Iseman MDSyndrome and pancreatic disease, subcutaneous fat necrosis and polyserositis: Case report and review of literature. Am J Med 1975; 58:417-423.

[9] Radin DR, Colletti PM, Forrester DM, Tang WW, Pancreatic acinar cell carcinoma with subcutaneous and intraosseous fat necrosis. Radiology 1986; 158:67-68.

[10] van Klaveren RJ, de Mulder PH, Boerbooms AM, van de Kaa CA, van Haelst UJ, Wagener DJ, Hafkenscheid JC. Pancreatic carcinoma with polyarthritis, fat necrosis, and high serum lipase and trypsin activity. Gut 1990; 31: 953-955.

[11] Wisnoski NC, Townsend CM Jr, Nealon WH, Freeman JL, Riall TS. 672 patients with acinar cell carcinoma of the pancreas: A population-based comparison to pancreatic adenocarcinoma. Surgery 2008; 144:141-148.

[12] Schmidt CM, Matos JM, Bentrem DJ, Talamonti MS, Lillemoe KD, Bilimoria KY.. Acinar cell carcinoma of the pancreas in the United States: prognostic factors and comparison to ductal adenocarcinoma. J Gastrointest Surg 2008; 12:2078-2086.

[13] Chiou YY, Chiang JH, Hwang JI, Yen CH, Tsay SH, Chang CY.. "Acinar cell carcinoma of the pancreas: clinical and computed tomography manifestations. J Comput Assist Tomogr 2004; 28 (2): $180-6$.

[14] Morohoshi T, Kanda M, Horie A, Chott A, Dreyer T, Klöppel G, Heitz PU.1.) Immunocytochemical markers of uncommon pancreatic tumors: Acinar cell carcinoma, pancreatoblastoma, and solid cystic (papillary-cystic) tumor. Cancer 1987; 59:739-747.

[15] Furlan D, Sahnane N, Bernasconi B, Frattini M, Tibiletti MG, Molinari F, et al. APC alterations are frequently involved in the pathogenesis of acinar cell carcinoma of the pancreas, mainly through gene loss and promoter hypermethylation. Virchows Arch. (2014); 464 (5):553-64. doi: 10.1007/s00428-014-1562-1. Epub 2014 Mar 4.

[16] La Rosa, S., Bernasconi, B., Frattini, M., Tibiletti MG., Molinari F., Furlan D. et al., TP53 alterations in pancreatic acinar cell carcinoma: new insights into the molecular pathology of this rare cancer. Virchows Arch (2016) 468: 289. doi:10.1007/s00428-015-1882-9

[17] Holen I, Croucher PI, Hamdy FC, Eaton CL Osteoprotegerin (OPG) is a survival factor for human prostate cancer cells. Cancer Res 2002; 62:1619-1623.

[18] Burns WA, Matthews MJ, Hamosh M, Weide GV, Blum R, Johnson FB. Lipase-secreting acinar cell carcinoma of the pancreas with polyarthropathy: A light and electron microscopic, histochemical, and biochemical study. Cancer 1974; 33:1002-1009. 
Acinar Cell Carcinoma of the Pancreas with Postoperative Lipase Hyper-Secretion Syndrome: Case Report and Review of the Literature

[19] Kitagami H, Kondo S, Hirano S, Kawakami H, Egawa S, Tanaka M. Acinar cell carcinoma of the pancreas: clinical analysis of 115 patients from Pancreatic Cancer Registry of Japan Pancreas Society. Pancreas 2007; 35:42-46.

[20] Distler M, Rückert F, Dittert DD, Stroszczynski C, Dobrowolski F, Kersting S, Grützmann R. Curative resection of a primarily unresectable acinar cell carcinoma of the pancreas after chemotherapy. World J Surg Oncol 2009; 7:22.

[21] Holen KD, Klimstra DS, Hummer A, Gonen M, Conlon K, Brennan M, Saltz LB. Clinical characteristics and outcomes from an institutional series of acinar cell carcinoma of the pancreas and related tumors. J Clin Oncol 2002; 20: 4673-4678. 